\title{
Ephrin-Eph signaling as a potential therapeutic target for the treatment of myocardial infarction
}

\author{
Wesley T. O'Neal ${ }^{a}$, William F. Griffin ${ }^{a}$, Jessica L. Dries-Devlin ${ }^{b}$, Susan D. Kent ${ }^{\mathrm{a}}$, Jin \\ Chen $^{\mathrm{c}, \mathrm{d}, \mathrm{e}, \mathrm{f}}$, Monte S. Willis ${ }^{\mathrm{g}}$, and Jitka A.I. Virag ${ }^{\mathrm{a},{ }^{*}}$ \\ aDepartment of Physiology, Brody School of Medicine, East Carolina University, Greenville, NC, \\ USA \\ ${ }^{b}$ Department of Biomedical Engineering, University of Minnesota, Minneapolis, MN, USA \\ 'Department of Medicine, Vanderbilt University, Nashville, TN, USA \\ ${ }^{d}$ Department of Cancer Biology, Vanderbilt University, Nashville, TN, USA \\ eDepartment of Cell \& Developmental Biology, Vanderbilt University, Nashville, TN, USA \\ fVeterans Affairs Medical Center, Tennessee Valley Healthcare System, Nashville, TN, USA \\ gDepartment of Pathology and Laboratory Medicine and McCallister Heart Institute, University of \\ North Carolina School of Medicine, Chapel Hill, NC, USA
}

\begin{abstract}
Although numerous strategies have been developed to reduce the initial ischemic insult and cellular injury that occurs during myocardial infarction (MI), few have progressed into the clinical arena. The epidemiologic and economic impact of MI necessitates the development of innovative therapies to rapidly and effectively reduce the initial injury and subsequent cardiac dysfunction. The Eph receptors and their cognate ligands, the ephrins, are the largest family of receptor tyrosine kinases, and their signaling has been shown to play a diverse role in various cellular processes. The recent advances in the study of ephrin- Eph signaling have shown promising progress in many fields of medicine. They have been implicated in the pathophysiology of various cancers and in the regulation of inflammation and apoptosis. Recent studies have shown that manipulation of ephrin-Eph cell signaling can favorably influence cardiomyocyte viability and ultimately preserve cardiac function post-MI. In this article, we explore the hypothesis that manipulation of ephrin-Eph signaling may potentially be a novel therapeutic target in the treatment of MI through alteration of the cellular processes that govern injury and wound healing.
\end{abstract}

\section{Introduction}

Cardiovascular disease (CVD) is accountable for nearly 1 in every 3 deaths in the United States at an annual cost of $\$ 149$ billion dollars [1,2]. Over the next 20 years, the prevalence of CVD will increase by $10 \%$ with a 3 -fold increase in cost [3]. Every year, 980,000 Americans will suffer from a new myocardial infarction (MI) and 470,000 will experience a recurrent event [1]. Furthermore, MI is associated with an increased risk of heart failure (HF) [4], and this disease alone is projected to increase by $25 \%$ with an $80 \%$ increase in cost by 2030 [3].

"Corresponding author. Address: Department of Physiology, LSB-239, Brody School of Medicine, East Carolina University, 600 Moye Blvd, Greenville, NC 27834, USA. Tel.: +1 252744 2777; fax: +1 252744 5477. viragj@ecu.edu (J.A.I. Virag). 
Occlusion due to the embolization of an unstable coronary plaque is the most common cause of MI [5]. Myocardial necrosis begins within $40 \mathrm{~min}$ of coronary occlusion and becomes transmural within $14 \mathrm{~h}[6,7]$. Structural remodeling of the myocardial architecture in both the infarcted area and non-infarcted area ensues, leading to progressive ventricular dilation, dysfunction, and a decline in systolic function that leads to symptoms of HF [7,8]. The critical time frame during which it is necessary to treat MI to limit functional decline make it of paramount importance to develop novel therapeutics that can be delivered during the ischemic event to reduce the acute injury and prevent subsequent cardiac dysfunction.

Current therapies for acute MI are aimed at reducing myocardial oxygen demand and improving blood flow to nonreperfused myocardium. Percutaneous coronary intervention and anti-thrombotic therapies have been shown to reduce myocardial injury through reperfusion of the ischemic myocardium when performed before irreversible cardiomyocyte (CM) necrosis occurs [9]. Numerous experimental paradigms have shown that reducing inflammation or promoting angiogenesis in conjunction with grafting cells during the early stage of injury have reduced adverse remodeling and cardiac dysfunction [10-13]. Granulocyte colony-stimulating factor (G-CSF), the only protein that has progressed to clinical trials, has been shown to moderately improve cardiac function after MI but the data remains controversial [14]. Recent evidence also suggests that manipulating the cell signaling that governs necrosis, apoptosis, and autophagy may enhance CM survival and ultimately preserve function following MI [15-19]. Although much research has been conducted to reduce acute ischemic injury, none have yet proven to be clinically beneficial.

\section{Hypothesis}

The Eph receptors and their cognate ligands, the ephrins, are the largest family of receptor tyrosine kinases and have been shown to play diverse roles in differentiation, proliferation, and migration of various cell types during development [20,21]. These receptors and their ligands have recently become of noted interest in the study of various cancers and immune function [22-26]. The role of these receptors and their ligands in the heart is a new and exciting area of exploration.

Our lab and others have shown that ephrin ligands and their interaction with the Eph receptors might be beneficial in the treatment of MI [27,28]. Originally known for its angiogenic properties, we thought ephrin $\mathrm{A} 1-\mathrm{Fc}$ would accelerate revascularization and thereby improve myocardial infarct healing. However, our published data and others indicate that this is not the case. By influencing $\mathrm{CM}$ survival and possibly regeneration, some combination of ephrinA1's stimulation and/or inhibition of EphA receptors may result in $\mathrm{CM}$ protection.

Therefore, we propose that the signaling cascade used by the EphA family of receptor tyrosine kinases and their cognate ligands can be manipulated as a potential therapeutic target in the treatment of MI. We will briefly discuss the pathophysiology of MI and what is currently known about ephrin-Eph signaling in wound healing and the heart to explain our hypothesis.

\section{Pathophysiology of myocardial infarction}

During an ischemic event, $\mathrm{CM}$ death progresses from the suben-docardium toward the epicardium in a transmural manner [6]. Stressed and necrotic cells in the ischemic myocardium release a host of proteins that recruit inflammatory cells to the area of injury and T-cells are known to amplify the inflammatory response through production of cytokines that result in the release of reactive oxygen species (ROS) [29,30]. Within $24 \mathrm{~h}$ of infarction, neutrophils begin to infiltrate from the periphery and macrophages follow within 
$72 \mathrm{~h}$. Most neutrophils undergo apoptosis within the first few days but macrophages persist in the infarcted area, outnumbering neutrophils 2-3 days after the initial insult [31]. In mice, between 4-7 days, granulation tissue, comprised of inflammatory cells, proliferating fibroblasts, and endothelial cells, forms by migration of these cells from the border zone into the infarct area [32]. During this process, a variety of factors are released from macrophages, including chemokines such as MCP-1, cytokines such as IL- $1 \beta$ and G-CSF, and ROS, such as nitric oxide and super-oxide anion [33-35]. In addition to the phagocytosis of necrotic cells, macrophages also are known to influence neovascularization by remodeling the extracellular matrix to form tunnels which will subsequently be populated by proliferating and/or migratory vascular cells [36-38]. These molecules, although essential components of the inflammatory response that aid in the termination of CM damage, also can cause considerable damage to surrounding viable cells that leads to spreading of the infarct.

The extracellular matrix is constantly remodeled in the normal myocardium to maintain normal cardiac function through production of interstitial collagen by cardiac fibroblasts. During infarction, cytokines, MCP-1, and IL- $1 \beta$ recruit myofibroblasts to the region of injury where, along with fibroblasts, they begin to deposit collagen to form fibrotic scar tissue [29]. The breakdown of intercellular collagen begins by the loss of homeostasis that exists between tissue inhibitors of matrix metalloproteinases (TIMPs) and matrix metalloproteinases (MMPs). The loss of inhibition on MMPs results in the post-translational cleavage of these proteins that propagates tissue degradation within hours of the infarction and propagates for days $[39,40]$. As the matrix disintegrates, myocyte slippage occurs $[41,42]$. Necrotic CMs, evidenced by contraction bands and pyknosis, and dead vascular elements are completely phagocytosed by macrophages within 2 weeks $[43,44]$. By this time, the young scar is characterized by the parallel organization of fibroblasts and a predominance of type I collagen [45]. The extracellular matrix becomes increasingly more fibrotic and surrounding endothelial cells, fibroblasts, and macrophages undergo apoptosis [8]. Volume-overload and subsequent hypertrophy of the surviving myocardium ensues with progressive thinning and stretching of the non-contractile scar tissue. The resultant increase in ventricular chamber dimensions and myocardial wall stress ultimately leads to inadequate functional capacity [46].

\section{Ephrin-Eph signaling}

Two subclasses of ephrin ligands exist and they are classified by how they are linked to the plasma membrane. EphrinA ligands are anchored to the cell membrane by a glycosylphosphotidyl-inositol (GPI) linkage while ephrinB ligands are transmembrane-spanning [47]. Ligands A1-A5 and B1-B3 are typically membrane-bound but a few soluble isoforms are secreted $[48,49]$.

Cell-to-cell contact or release of the soluble ephrin ligand results in binding to the Eph receptors, A1-A8, B1-B4, and B6, which leads to dimerization, tetramerization, and/or clustering of ligands and receptors resulting in the activation or silencing of bidirectional signaling and consequent activation, or inhibition of intracellular cascades in both cells [50,51]. This intercellular communication strategy in adhesion and repulsion is a key feature of their involvement in boundary formation between arteries and veins during blood vessel development [52].

Direct cell-to-cell interaction of these proteins is required to elicit signaling in the direction of both the ligand-expressing cell and the receptor-expressing cell. Signaling in both directions of the contacting cells has been termed bidirectional signaling [53]. It also has been proposed that the ligand and receptor may be expressed on the surface of the same cell. Ephrin-Eph cis interaction may actually work to silence bidirectional signaling [47]. More 
recently, EphA and EphB receptors have been shown to interact forming heterotypic clusters upon ligand binding that results in activation or inhibition depending on the Eph receptor cell surface expression profile [54].

Of the 5 ephrinA ligands, only ephrinA1 has been shown to bind to all EphA receptors. EphrinA1 was originally described as a gene product induced by TNF-a to precondition the vascular endothelial cells to pro-inflammatory cytokines [55]. EphrinA1 also has been shown to be released as an active soluble monomer to alter molecular signaling to influence the biology of certain cancers [51]. The function of ephrinA1-EphA activation or silencing of bidirectional signaling and consequent activation or inhibition of intracellular cascades in the heart and in response to ischemic injury is a new area of investigation.

To understand the potential role of these proteins in modulating the injury during MI, it is necessary to examine what is known about ephrin-Eph signaling in inflammation, cell death, angiogenesis, hypertrophy, and fibrosis.

\section{Ephrin-Eph signaling in wound healing}

\section{Inflammation and oxidative stress}

Ephrin ligands and Eph receptors are expressed in the vascular endothelium and leukocytes, and their expression can be enhanced by pro-inflammatory cytokines [56]. Additionally, it has been shown that activation of EphA2 in vascular endothelial cells induces gene expression of inflammatory cytokines and recruits inflammatory cells [57]. During the early stages of inflammation, EphA2 and ephrinB2 expression is localized to the vascular epithelial and endothelial cells, promoting disruption of the endothelial/ epithelial barrier. As the inflammatory process progresses, expression of EphA1, A3, B3, and B4 decreases, permitting infiltrating leukocytes to adhere to endothelial cells by disrupting endothelial/ epithelial barriers [56]. Reorganization of the actin cytoskeleton required for migration of Tcells, widely recognized for their role in immune surveillance and initiation of the immune response, may be influenced by ephrinA1-EphA signaling since these cells have been shown to express EphA1-4, A7, and A8 [58,59]. Mice lacking EphA4 have thymic hypoplasia and decreased peripheral T-cells, and this was demonstrated to be due to increased apoptosis and reduced cell cycling [60]. EphrinA1 expression in peripheral T-cells of asthmatics also has been shown to be reduced and this has been linked to overproduction of cytokines from increased numbers of activated Th2 cells [61,62]. EphrinA1 stimulation of $\mathrm{T}$-cells prevents chemotaxis and may be a negative regulator of inflammation [63]. Sharfe et al. proposed that ephrinA1 enhances integrin-mediated adhesive interactions between Tcells and endothelial cells while EphA receptor activation of T-cells inhibits it, thus restricting T-cell transmigration [64]. T-cells have been shown to be involved in the early recruitment of neutrophils and macrophages in ischemic myocardium [65] as well as in the later stages of remodeling [66]. Also, inhibition of T-cell accumulation in the infarct zone during MI has been shown to reduce infarct size [65].

The nature of ephrinA1-EphA interactions in the myocardium remains incomplete. Whether the ligand and/or receptors are upregulated or downregulated and how their expression changes over time will most certainly be important in fully understanding the mechanisms of their action during MI.

\section{Necrosis, apoptosis, and autophagy}

The cumulative loss of functioning CMs following MI progresses as an imbrication of necrotic cell death, apoptosis, and autophagy. Within the first $24 \mathrm{~h}$, extensive loss of CMs is due to ischemic necrosis $[67,68]$. Subsequent cell death in the peri-infarct zone is largely due to apoptosis and occurs in response to distinct cellular signals [69]. 
Depaepe et al. observed that EphA7 expression in embryonic cortical progenitors positively regulates apoptosis to prevent overgrowth by showing that functional deletion of this gene reduced apoptosis and that ectopic expression of ephrinA5 directly opposed this action [70]. Between 2 and 28 days following experimental induction of spinal cord injury in rats, there is a dynamic change in EphA7 expression in the acute versus chronic stages of repair, reflecting the vital role of this receptor in modulating apoptosis to prevent secondary damage [71]. Also, soluble EphA2-Fc and EphA3-Fc treatment of mice with VEGFdependent pancreatic carcinoma resulted in the promotion of endothelial cell apoptosis [72]. Most recently, Jehle et al. [73] observed that increased EphA2 phosphorylation in immortalized HL-1 cardiomyocytes treated with doxazocin results in apoptosis. Lithocholic acid administration reduced apoptosis by increasing EphA2-R expression and decreasing EphA2 phosphorylation [73]. Removal of the ephrinB3 ligand from EphA4 has been shown to result in caspase-dependent cell death [74] and EphA4-deficient mice have increased numbers of apoptotic cells, further implicating EphA4 forward signaling in the inhibition of cellular apoptosis [60]. Additionally, there is evidence that ephrinA reverse signaling can result in Akt phosphorylation and inhibition of apoptosis [75]. There may be synergistic effects of ephrinA1 with growth factors such as FGF2 in cells that co-express EphA4 and FGFRs [76]. It is possible that some combination of changes in the EphA level, phosphorylation, and signaling may determine the rate of apoptosis of different cell types following ischemic injury.

The final phase of CM death, which can progress for months, is autophagy. Autophagy is a process by which, at low levels under normal circumstances in a healthy heart, intracellular proteins and organelles are removed by lysosomal degradation. This is an important adaptive feature of terminally differentiated CMs to survive hypoxic conditions by removing intracellular debris and providing substrates for ATP generation. This also can occur in the injured myocardium [77,78]. Upregulation of p62 and the ratio of LC3-II/I (microtubuleassociated protein-1 light chain 3-II) are indications of autophagic activation [79]. Beclin-1 and atg7 also are markers of autophagy and beclin-1 is upregulated in response to ischemia and is inhibited by the anti-apoptotic protein bcl-2 [80]. In addition to enhancing the antiapoptotic effects of the bcl-2 protein, it has been shown that the BAG-1 protein can induce protective autophagy in a rat model of ischemia-reperfusion by linking heat shock proteins Hsc70/Hsp70 with the proteasome [81]. The role of ephrin-Eph signaling in this process in the ischemic myocardium has yet to be elucidated.

\section{Angiogenesis}

In addition to reducing inflammation, post-infarct revascularization is a critical facet of myocardial salvage. Sprouting from pre-existing vessels requires that the endothelial cells dissociate, mobilize, migrate into the ischemic area, proliferate, convene to form tubules, and recruit mural cells which will stabilize the structure with extracellular matrix deposition [82]. Studies of the function of the pro-angiogenic ephrinA1 protein and the EphA receptor family in this process have been largely restricted to models of corneal angiogenesis and tumorigenesis [83]. A few studies have shown that in endothelial cells, ephrinA1, induced by TNF- $\alpha$, IL-1 $\beta$, and VEGF, can stimulate cell adhesion via $\alpha_{v}-\beta_{3}$ integrin and result in cytoskeletal alterations that inhibit cellular spreading and cause vessel destabilization, a prerequisite for neovascularization $[84,85]$. EphA1 expression also has been shown to be induced by VEGF and TNF-a, and this has been shown to cause endothelial cell migration and angiogenesis [86]. The loss of EphA2, through anti-sense EphA2 RNA, limits tumorigenesis in a model of colorectal cancer through inhibition of ephrinA1-induced expression of VEGF-induced angiogenesis, whereas overexpression of EphA2 in tumor cells is associated with increased vascular density and ephrinA1 expression is increased in radioresistant tumors in mice $[87,88]$. It has been suggested that these paradoxical pro- and 
anti-angiogenic properties attributed to EphA2 during tumor progression are related to Aktdependent phosphorylation of EphA2 [89]. More recently, the ligand Slit2 has been shown to regulate angiogenesis and this process is influenced by the presence or absence of ephrinA1 $[90,91]$. This also may be related to the notion that overexpression of EphA2 causes loss of the expression of its ligand [92]. Brantley-Sieders et al. showed that ephrinA1-stimulated primary bovine and murine pulmonary microvascular endothelial cells resulted in vascular assembly and migration, whereas, the angiogenic response was blunted in EphA2-deficient cells [93]. Furthermore, EphA2-deficient mice exhibited hyperresponsiveness to allergens demonstrated by increased inflammation and defective capillary growth [94].

EphA2 and EphA4 also have been shown to be expressed on vascular smooth muscle cells (VSMCs) and there may be crosstalk between endothelial cells and surrounding pericytes $[95,96]$. EphA6 and EphA7, expressed on vascular endothelium, are involved in angiogenesis [97,98]. Ephrin-Eph signaling has been implicated to play a role in extracellular matrix remodeling [99], however, their role during ischemia is unknown.

\section{Hypertrophy and fibrosis}

The process of extracellular matrix remodeling combined with migration, proliferation, and differentiation of fibroblasts into myofibroblasts that synthesize collagen causes interstitial and perivascular fibrosis leading to stiffening of the ventricle, vascular dysfunction, and formation of scar tissue that replaces the necrotic myocardium [100,101]. Additionally, increased numbers of mast cells in the later phase of wound healing can release proteases that increase MMP activity and exacerbate the progression of fibrosis and remodeling [102104]. Extracellular matrix components, such as fibronectin-EDA, are critical for activating myofibroblasts and also can negatively impact the inflammatory response and subsequent remodeling [105]. Molecules, such as HMGB1 which is involved in inflammation, fibrosis, and CM hypertrophy [106,107], as well as FAK and p38 MAPK, may influence cell motility and CM hypertrophy [108]. These mediators are downstream targets of pathways that also can be affected by ephrin-Eph receptor activation. For example, inhibition of cell spreading and integrin-mediated adhesion resulting from dephosphorylation of FAK occurs in response to EphA2 stimulation by ephrinA1 [109,110] and FAK-null mouse embryonic fibroblasts have a defective response to ephrinA1-induced cytoskeletal changes [111]. FAKdeletion exacerbates apoptosis and infarct size [112] and promotes myofibroblast differentiation [113]. The pattern of ephrin-Eph expression in CMs and myofibroblasts and their involvement in matrix remodeling, interstitial fibrosis, hypertrophy, and scar formation are currently unknown.

\section{Evaluation of the hypothesis: ephrin-Eph signaling as a cardiovascular therapeutic target}

Several studies have investigated the role of ephrin-Eph signaling in the context of myocardial repair or regeneration after MI. Based on the properties described earlier, it is reasonable to suggest that these cell surface proteins may promote angiogenesis or reduce CM death after an ischemic insult through manipulation of other cell processes involved in wound healing (Fig. 1). We will now discuss the current studies that have explored ephrinEph signaling in the myocardium (Table 1).

The first report was published in 2008 by Mansson-Broberg and colleagues [114]. The authors induced $\mathrm{MI}$ in mice through permanent coronary artery occlusion and then assessed mRNA levels of the EphB4 receptor and the ephrinB2 ligand in CMs 2 weeks post-MI. At each time point examined, they found the ligand and receptor were inversely expressed. The 
ephrinB2 chimeric protein, ephrinB2-Fc, also induced endothelial cell proliferation and sprouting when used in vitro. Following MI, mice that were treated with an injection of ephrinB2-Fc had a $28 \%$ increase in capillary density in the peri-infarct region, and a trend towards increased mitotic activity. However, the authors did not comment on the reduction of infarct size or echocardiographic function. These data do suggest that a single, systemic dose of ephrinB2-Fc is sufficient to activate the EphB4 receptor and this may promote angiogenesis, although the extent of cardioprotection has not been determined.

Our group recently published the gene expression pattern of EphA receptors and the ephrinA1 ligand in the healthy murine myocardium and in response to nonreperfused MI $[27,115]$. Expression of the ephrinA1 protein was seen in CMs throughout the myocardium and expression increased post-MI. To test the therapeutic role of this system the ephrinA1Fc chimera was injected directly into the myocardium of mice immediately following permanent coronary occlusion. This resulted in a significant modulation of mRNA expression of several Eph receptors, suggesting that beneficial changes in ligand-receptor binding had occurred. Expression of EphA1-A3 and EphA7 were significantly increased following MI while EphA6 expression decreased. Treatment with ephrinA1-Fc further increased EphA1 and EphA2 gene expression and resulted in a 2-fold increase in EphA4. Importantly, infarct size was significantly reduced, along with inflammatory cell infiltration and cardiac troponin I release. Treatment with ephrinA1-Fc also increased phosphorylated Akt protein expression, reduced PARP cleavage, and increased BAG-1 expression, indicative of improved cellular survival via reduction in apoptosis and possibly enhanced autophagy. These data represent a cardioprotective role for exogenous ephrinA1-Fc administration in the setting of acute MI and may present a novel therapeutic approach to be used alone or in conjunction with stem/progenitor cells or other biomaterials. Additionally, Frieden et al. generated ephrinA1-null mice in which they observed defective valve morphogenesis during development and reduced ejection fraction and fractional shortening in adult mice, not due to changes in blood pressure, but rather due to intrinsic cardiac dysfunction [116]. Collaborative studies are in progress to further explore the adult cardiac phenotype and response to acute and chronic injury.

Subsequently, Goichberg et al. investigated the role of ephrinA1 in myocardial repair [28]. In agreement with our findings, they observed ephrinA1 protein expression on CMs. Furthermore, they showed that treatment of human cardiac stem cells (hCSCs) in vitro resulted in increased cellular motility, as well as in vivo following MI. Infarct size was reduced by $37 \%$ and the volume of the myocardium increased 2-fold with ephrinA1activated hCSCs compared to control hCSCs. Treatment with ephrinA1-activated hCSCs ultimately increased ventricular pressure and ejection fraction after MI compared to controls [28], although the relative contribution of cardiac stem cells to CM regeneration versus neoangiogenesis remains unclear. Again, these data implicate a critical role for ephrinA1 signaling in the context of myocardial repair and present a new and exciting area in the development of therapies to repair the myocardium after MI.

Genet et al. have described a role of ephrinB1 in the murine heart [117]. Although this study did not include an experimental model of MI, their characterization of the expression of ephrinB1 in the murine heart provides further evidence for the role of ephrinB1 in CM stability. EphrinB1-deficient mice were shown to have a more disorganized CM structure and extracellular matrix compared to control mice. Claudin-5, a protein involved in CM stability, was noted to be decreased in mice deficient of ephrinB1 and cardiac sarcomere disorganization was noted by electron microscopy. EphrinB1-deficient mice also were observed to have more dilation of the left ventricle during diastole, decreased atrioventricular conduction evidenced by lengthening of the PR interval, and had a poorer survival with ascending aortic banding and subsequent pressure overload than controls. 
These results highlight the pivotal role for ephrinB1 in cardiac tissue and its capacity to preserve cardiac function during times of stress.

\section{Consequences of the hypothesis and conclusions}

Although numerous therapies have been and are currently being investigated to treat MI, very few have shown any promise to be clinically applicable. The economic impact of MI on our healthcare system necessitates the development of novel therapeutics to reduce the initial injury and blunt the progressive cardiac dysfunction. The current standard of care revolves around the implementation of early reperfusion of the ischemic myocardium within a critical time period to preserve CM viability while neglecting any aspect that could alter the biological basis for the injury observed during and after infarction.

The recent advances in the study of ephrin-Eph signaling have shown promising progress in many fields of medicine. Ephrin-Eph signaling has been shown to regulate inflammation and apoptosis in other tissues and also possibly reduce the extent of these injurious processes during the early phases of the ischemic insult. Although there are no reports that show their signaling directly enhances autophagy during MI, we hypothesize that their activation will be beneficial during ischemia. Ephrin-Eph signaling also has been reported to be pro-angiogenic and many of the downstream targets of its signaling pathway could negatively influence the effects of hypertrophy and fibrosis during wound healing. Once a more detailed understanding of ephrin-Eph signaling during ischemia is uncovered, we will then be able to evaluate the potential impact of this signaling pathway in the treatment of MI.

\section{Acknowledgments}

Jitka Virag, PhD is supported by a North Carolina Biotech Center Biotechnology Research Grant as well as the Departments of Physiology, Comparative Medicine, and the East Carolina Diabetes and Obesity Institute. Jin Chen MD, PhD is supported by Department of Veterans Affairs through a VA Merit Award and NIH RO1CA95004. Monte S. Willis MD, PhD is supported by NIH RO1HL104129 and the Leducq Foundation.

\section{References}

1. Lloyd-Jones D, Adams RJ, Brown TM, et al. Executive summary: heart disease and stroke statistics-2010 update: a report from the American Heart Association. Circulation. 2010; 121:948954. [PubMed: 20177011]

2. Trogdon JG, Finkelstein EA, Nwaise IA, Tangka FK, Orenstein D. The economic burden of chronic cardiovascular disease for major insurers. Health Promot Pract. 2007; 8:234-242. [PubMed: 17606951]

3. Heidenreich PA, Trogdon JG, Khavjou OA, et al. Forecasting the future of cardiovascular disease in the United States: a policy statement from the American Heart Association. Circulation. 2011; 123:933-944. [PubMed: 21262990]

4. Kannel WB. Incidence and epidemiology of heart failure. Heart Fail Rev. 2000; 5:167-173. [PubMed: 16228142]

5. White HD, Chew DP. Acute myocardial infarction. Lancet. 2008; 372:570-584. [PubMed: 18707987]

6. Reimer KA, Jennings RB. The "wavefront phenomenon" of myocardial ischemic cell death. II. Transmural progression of necrosis within the framework of ischemic bed size (myocardium at risk) and collateral flow. Lab Invest. 1979; 40:633-644. [PubMed: 449273]

7. Jugdutt BI. Ischemia/Infarction. Heart Fail Clin. 2012; 8:43-51. [PubMed: 22108726]

8. Frangogiannis NG, Smith CW, Entman ML. The inflammatory response in myocardial infarction. Cardiovasc Res. 2002; 53:31-47. [PubMed: 11744011] 
9. Keeley EC, Hillis LD. Primary PCI for myocardial infarction with ST-segment elevation. N Engl J Med. 2007; 356:47-54. [PubMed: 17202455]

10. Woo YJ, Panlilio CM, Cheng RK, et al. Therapeutic delivery of cyclin A2 induces myocardial regeneration and enhances cardiac function in ischemic heart failure. Circulation. 2006; 114:I2061213. [PubMed: 16820573]

11. Yau TM, Li G, Weisel RD, et al. Vascular endothelial growth factor transgene expression in celltransplanted hearts. J Thorac Cardiovasc Surg. 2004; 127:1180-1187. [PubMed: 15052220]

12. Trescher K, Bernecker O, Fellner B, et al. Inflammation and postinfarct remodeling: overexpression of IkappaB prevents ventricular dilation via increasing TIMP levels. Cardiovasc Res. 2006; 69:746-754. [PubMed: 16388787]

13. Sugano M, Tsuchida K, Hata T, Makino N. In vivo transfer of soluble TNF-alpha receptor 1 gene improves cardiac function and reduces infarct size after myocardial infarction in rats. FASEB J. 2004; 18:911-913. [PubMed: 15117889]

14. Abdel-Latif A, Bolli R, Zuba-Surma EK, Tleyjeh IM, Hornung CA, Dawn B. Granulocyte colonystimulating factor therapy for cardiac repair after acute myocardial infarction: a systematic review and meta-analysis of randomized controlled trials. Am Heart J. 2008; 156:216-226. [PubMed: 18657649]

15. French CJ, Taatjes DJ, Sobel BE. Autophagy in myocardium of murine hearts subjected to ischemia followed by reperfusion. Histochem Cell Biol. 2010; 134:519-526. [PubMed: 20931339]

16. Hamacher-Brady A, Brady NR, Gottlieb RA. Enhancing macroautophagy protects against ischemia/reperfusion injury in cardiac myocytes. J Biol Chem. 2006; 281:29776-29787. [PubMed: 16882669]

17. Shaw J, Kirshenbaum LA. Molecular regulation of autophagy and apoptosis during ischemic and non-ischemic cardiomyopathy. Autophagy. 2008; 4:427-434. [PubMed: 18367871]

18. Kung G, Konstantinidis K, Kitsis RN. Programmed necrosis, not apoptosis, in the heart. Circ Res. 2011; 108:1017-1036. [PubMed: 21493924]

19. Kanamori H, Takemura G, Goto K, et al. The role of autophagy emerging in postinfarction cardiac remodelling. Cardiovasc Res. 2011; 91:330-339. [PubMed: 21406597]

20. Pasquale EB. Eph-ephrin bidirectional signaling in physiology and disease. Cell. 2008; 133:38-52. [PubMed: 18394988]

21. Kullander K, Klein R. Mechanisms and functions of Eph and ephrin signalling. Nat Rev Mol Cell Biol. 2002; 3:475-486. [PubMed: 12094214]

22. Brantley DM, Cheng N, Thompson EJ, et al. Soluble Eph A receptors inhibit tumor angiogenesis and progression in vivo. Oncogene. 2002; 21:7011-7026. [PubMed: 12370823]

23. Yamashita T, Ohneda K, Nagano M, et al. Hypoxia-inducible transcription factor-2alpha in endothelial cells regulates tumor neovascularization through activation of ephrinA1. J Biol Chem. 2008; 283:18926-18936. [PubMed: 18434321]

24. Landen CN, Kinch MS, Sood AK. EphA2 as a target for ovarian cancer therapy. Expert Opin Ther Targets. 2005; 9:1179-1187. [PubMed: 16300469]

25. McCarron JK, Stringer BW, Day BW, Boyd AW. Ephrin expression and function in cancer. Future Oncol. 2010; 16:165-176. [PubMed: 20021216]

26. Hafner C, Becker B, Landthaler M, Vogt T. Expression profile of Eph receptors and ephrin ligands in human skin and downregulation of EphA1 in nonmelanoma skin cancer. Mod Pathol. 2006; 19:1369-1377. [PubMed: 16862074]

27. Dries JL, Kent SD, Virag JA. Intramyocardial administration of chimeric ephrinA1-Fc promotes tissue salvage following myocardial infarction in mice. J Physiol. 2011; 589:1725-1740. [PubMed: 21282286]

28. Goichberg P, Bai Y, D'Amario D, et al. The ephrinA1-EphA2 system promotes cardiac stem cell migration after infarction. Circ Res. 2011; 108:1071-1083. [PubMed: 21415392]

29. Frangogiannis NG. Chemokines in ischemia and reperfusion. Thromb Haemostasis. 2007; 97:738747. [PubMed: 17479184]

30. Frangogiannis NG. The immune system and cardiac repair. Pharmacol Res. 2008; 58:88-111. [PubMed: 18620057] 
31. Bodi V, Sanchis J, Nunez J, et al. Uncontrolled immune response in acute myocardial infarction: unraveling the thread. Am Heart J. 2008; 156:1065-1073. [PubMed: 19033000]

32. Virag JI, Murry CE. Myofibroblast and endothelial cell proliferation during murine myocardial infarct repair. Am J Pathol. 2003; 163:2433-2440. [PubMed: 14633615]

33. Nian M, Lee P, Khaper N, Liu P. Inflammatory cytokines and postmyocardial infarction remodeling. Circ Res. 2004; 94:1543-1553. [PubMed: 15217919]

34. Frangogiannis NG, Entman ML. Chemokines in myocardial ischemia. Trends Cardiovasc Med. 2005; 15:163-169. [PubMed: 16165012]

35. Kumar D, Jugdutt BI. Apoptosis and oxidants in the heart. J Lab Clin Med. 2003; 142:288-297. [PubMed: 14647032]

36. Moldovan NI. Role of monocytes and macrophages in adult angiogenesis: a light at the tunnel's end. J Hematother Stem Cell Res. 2002; 11:179-194. [PubMed: 11983092]

37. Moldovan NI, Goldschmidt-Clermont PJ, Parker-Thornburg J, Shapiro SD, Kolattukudy PE. Contribution of monocytes/macrophages to compensatory neovascularization: the drilling of metalloelastase-positive tunnels in ischemic myocardium. Circ Res. 2000; 87:378-384. [PubMed: 10969035]

38. Anghelina M, Krishnan P, Moldovan L, Moldovan NI. Monocytes and macrophages form branched cell columns in matrigel: implications for a role in neovascularization. Stem Cells Dev. 2004; 13:665-676. [PubMed: 15684834]

39. Schulze CJ, Wang W, Suarez-Pinzon WL, Sawicka J, Sawicki G, Schulz R. Imbalance between tissue inhibitor of metalloproteinase-4 and matrix metalloproteinases during acute myocardial [correction of myoctardial] ischemia-reperfusion injury. Circulation. 2003; 107:2487-2492. [PubMed: 12707244]

40. Vanhoutte D, Schellings M, Pinto Y, Heymans S. Relevance of matrix metalloproteinases and their inhibitors after myocardial infarction: a temporal and spatial window. Cardiovasc Res. 2006; 69:604-613. [PubMed: 16360129]

41. Cleutjens JP, Kandala JC, Guarda E, Guntaka RV, Weber KT. Regulation of collagen degradation in the rat myocardium after infarction. J Mol Cell Cardiol. 1995; 27:1281-1292. [PubMed: 8531210]

42. Salih C, McCarthy KP, Ho SY. The fibrous matrix of ventricular myocardium in hypoplastic left heart syndrome: a quantitative and qualitative analysis. Ann Thorac Surg. 2004; 77:36-40. [PubMed: 14726030]

43. Baroldi G. Anatomy and quantification of myocardial cell death. Methods Achiev Exp Pathol. 1988; 13:87-113. [PubMed: 3045498]

44. Holmes JW, Borg TK, Covell JW. Structure and mechanics of healing myocardial infarcts. Annu Rev Biomed Eng. 2005; 7:223-253. [PubMed: 16004571]

45. Sun Y, Kiani MF, Postlethwaite AE, Weber KT. Infarct scar as living tissue. Basic Res Cardiol. 2002; 97:343-347. [PubMed: 12200633]

46. Pfeffer MA, Braunwald E. Ventricular remodeling after myocardial infarction. Experimental observations and clinical implications. Circulation. 1990; 81:1161-1172. [PubMed: 2138525]

47. Egea J, Klein R. Bidirectional Eph-ephrin signaling during axon guidance. Trends Cell Biol. 2007; 17:230-238. [PubMed: 17420126]

48. Mosch B, Reissenweber B, Neuber C, Pietzsch J. Eph receptors and ephrin ligands: important players in angiogenesis and tumor angiogenesis. J Oncol. 2010; 2010:135285. [PubMed: 20224755]

49. Blits-Huizinga CT, Nelersa CM, Malhotra A, Liebl DJ. Ephrins and their receptors: binding versus biology. IUBMB Life. 2004; 56:257-265. [PubMed: 15370889]

50. Hamada K, Oike Y, Ito Y, et al. Distinct roles of ephrin-B2 forward and EphB4 reverse signaling in endothelial cells. Arterioscler Thromb Vasc Biol. 2003; 23:190-197. [PubMed: 12588758]

51. Wykosky J, Palma E, Gibo DM, Ringler S, Turner CP, Debinski W. Soluble monomeric EphrinA1 is released from tumor cells and is a functional ligand for the EphA2 receptor. Oncogene. 2008; 27:7260-7273. [PubMed: 18794797]

52. Zhang J, Hughes S. Role of the ephrin and Eph receptor tyrosine kinase families in angiogenesis and development of the cardiovascular system. J Pathol. 2006; 208:453-461. [PubMed: 16470907] 
53. Holland SJ, Gale NW, Mbamalu G, Yancopoulos GD, Henkemeyer M, Pawson T. Bidirectional signalling through the EPH-family receptor Nuk and its transmembrane ligands. Nature. 1996; 383:722-725. [PubMed: 8878483]

54. Janes PW, Griesshaber B, Atapattu L, et al. Eph receptor function is modulated by heterooligomerization of A and B type Eph receptors. J Cell Biol. 2011; 195:1033-1045. [PubMed: 22144690]

55. Holzman LB, Marks RM, Dixit VM. A novel immediate-early response gene of endothelium is induced by cytokines and encodes a secreted protein. Mol Cell Biol. 1990; 10:5830-5838. [PubMed: 2233719]

56. Ivanov AI, Romanovsky AA. Putative dual role of ephrin-Eph receptor interactions in inflammation. IUBMB Life. 2006; 58:389-394. [PubMed: 16801213]

57. Funk SD, Yurdagul A Jr, Albert P, et al. EphA2 activation promotes the endothelial cell inflammatory response: a potential role in atherosclerosis. Arterioscler Thromb Vasc Biol. 2012; 32:686-695. [PubMed: 22247258]

58. Munoz JJ, Alonso CL, Sacedon R, et al. Expression and function of the Eph A receptors and their ligands ephrins A in the rat thymus. J Immunol. 2002; 169:177-184. [PubMed: 12077243]

59. Wu J, Luo H. Recent advances on T-cell regulation by receptor tyrosine kinases. Curr Opin Hematol. 2005; 12:292-297. [PubMed: 15928486]

60. Munoz JJ, Alfaro D, Garcia-Ceca J, Alonso CL, Jimenez E, Zapata A. Thymic alterations in EphA4-deficient mice. J Immunol. 2006; 177:804-813. [PubMed: 16818734]

61. Wohlfahrt JG, Karagiannidis C, Kunzmann S, et al. Ephrin-A1 suppresses Th2 cell activation and provides a regulatory link to lung epithelial cells. J Immunol. 2004; 172:843-850. [PubMed: 14707054]

62. Wohlfahrt JG, Kunzmann S, Menz G, et al. T cell phenotype in allergic asthma and atopic dermatitis. Int Arch Allergy Immunol. 2003; 131:272-282. [PubMed: 12915770]

63. Sharfe N, Freywald A, Toro A, Dadi H, Roifman C. Ephrin stimulation modulates T cell chemotaxis. Eur J Immunol. 2002; 32:3745-3755. [PubMed: 12516569]

64. Sharfe N, Nikolic M, Cimpeon L, Van De Kratts A, Freywald A, Roifman CM. EphA and ephrinA proteins regulate integrin-mediated T lymphocyte interactions. Mol Immunol. 2008; 45:12081220. [PubMed: 17980912]

65. Yang Z, Day YJ, Toufektsian MC, et al. Myocardial infarct-sparing effect of adenosine A2A receptor activation is due to its action on CD4+ T lymphocytes. Circulation. 2006; 114:20562064. [PubMed: 17060376]

66. Yu Q, Watson RR, Marchalonis JJ, Larson DF. A role for T lymphocytes in mediating cardiac diastolic function. Am J Physiol Heart Circ Physiol. 2005; 289:H643-H651. [PubMed: 16014617]

67. Tavernarakis N. Cardiomyocyte necrosis: alternative mechanisms, effective interventions. Biochim Biophys Acta. 2007; 1773:480-482. [PubMed: 17320988]

68. Golstein P, Kroemer G. Cell death by necrosis: towards a molecular definition. Trends Biochem Sci. 2007; 32:37-43. [PubMed: 17141506]

69. Abbate A, Bussani R, Biondi-Zoccai GG, et al. Infarct-related artery occlusion, tissue markers of ischaemia, and increased apoptosis in the peri-infarct viable myocardium. Eur Heart J. 2005; 26:2039-2045. [PubMed: 16030061]

70. Depaepe V, Suarez-Gonzalez N, Dufour A, et al. Ephrin signalling controls brain size by regulating apoptosis of neural progenitors. Nature. 2005; 435:1244-1250. [PubMed: 15902206]

71. Figueroa JD, Benton RL, Velazquez I, et al. Inhibition of EphA7 up-regulation after spinal cord injury reduces apoptosis and promotes locomotor recovery. J Neurosci Res. 2006; 84:1438-1451. [PubMed: 16983667]

72. Cheng N, Brantley D, Fang WB, et al. Inhibition of VEGF-dependent multistage carcinogenesis by soluble EphA receptors. Neoplasia. 2003; 5:445-456. [PubMed: 14670182]

73. Jehle J, Staudacher I, Wiedmann F, Schweizer P, Becker R, Katus H, et al. Regulation of apoptosis in HL-1 cardiomyocytes by phosphorylation of the receptor tyrosine kinase EphA2 and protection by lithocholic acid. Br J Pharmacol. 2012; 167:1563-1572. [PubMed: 22845314] 
74. Furne C, Ricard J, Cabrera JR, et al. EphrinB3 is an anti-apoptotic ligand that inhibits the dependence receptor functions of EphA4 receptors during adult neurogenesis. Biochim Biophys Acta. 2009; 1793:231-238. [PubMed: 18948148]

75. Holen HL, Shadidi M, Narvhus K, Kjosnes O, Tierens A, Aasheim HC. Signaling through ephrinA ligand leads to activation of Src-family kinases, Akt phosphorylation, and inhibition of antigen receptor-induced apoptosis. J Leukoc Biol. 2008; 84:1183-1191. [PubMed: 18593733]

76. Yokote H, Fujita K, Jing X, et al. Trans-activation of EphA4 and FGF receptors mediated by direct interactions between their cytoplasmic domains. Proc Natl Acad Sci USA. 2005; 102:1886618871. [PubMed: 16365308]

77. Dong Y, Undyala VV, Gottlieb RA, Mentzer RM Jr, Przyklenk K. Autophagy: definition, molecular machinery, and potential role in myocardial ischemia-reperfusion injury. J Cardiovasc Pharmacol Ther. 2010; 15:220-230. [PubMed: 20595626]

78. Przyklenk K, Undyala VV, Wider J, Sala-Mercado JA, Gottlieb RA, Mentzer RM. Acute induction of autophagy as a novel strategy for cardioprotection: getting to the heart of the matter. Autophagy. 2011; 7

79. Komatsu M, Waguri S, Koike M, et al. Homeostatic levels of p62 control cytoplasmic inclusion body formation in autophagy-deficient mice. Cell. 2007; 131:1149-1163. [PubMed: 18083104]

80. Pattingre S, Tassa A, Qu X, et al. Bcl-2 antiapoptotic proteins inhibit Beclin 1-dependent autophagy. Cell. 2005; 122:927-939. [PubMed: 16179260]

81. Gurusamy N, Lekli I, Gorbunov NV, Gherghiceanu M, Popescu LM, Das DK. Cardioprotection by adaptation to ischaemia augments autophagy in association with BAG-1 protein. J Cell Mol Med. 2009; 13:373-387. [PubMed: 18793351]

82. Patan S. Vasculogenesis and angiogenesis. Cancer Treat Res. 2004; 117:3-32. [PubMed: 15015550]

83. Wykosky J, Debinski W. The EphA2 receptor and ephrinA1 ligand in solid tumors: function and therapeutic targeting. Mol Cancer Res. 2008; 6:1795-1806. [PubMed: 19074825]

84. Moon JJ, Lee SH, West JL. Synthetic biomimetic hydrogels incorporated with Ephrin-A1 for therapeutic angiogenesis. Biomacromolecules. 2007; 8:42-49. [PubMed: 17206786]

85. Cheng N, Brantley DM, Chen J. The ephrins and Eph receptors in angiogenesis. Cytokine Growth Factor Rev. 2002; 13:75-85. [PubMed: 11750881]

86. Cheng N, Brantley DM, Liu H, et al. Blockade of EphA receptor tyrosine kinase activation inhibits vascular endothelial cell growth factor-induced angiogenesis. Mol Cancer Res. 2002; 1:2-11. [PubMed: 12496364]

87. Brantley-Sieders DM, Fang WB, Hwang Y, Hicks D, Chen J. Ephrin-A1 facilitates mammary tumor metastasis through an angiogenesis-dependent mechanism mediated by EphA receptor and vascular endothelial growth factor in mice. Cancer Res. 2006; 66:10315-10324. [PubMed: 17079451]

88. Nojiri K, Iwakawa M, Ichikawa Y, et al. The proangiogenic factor ephrin-A1 is up-regulated in radioresistant murine tumor by irradiation. Exp Biol Med (Maywood). 2009; 234:112-122. [PubMed: 18997097]

89. Miao H, Li DQ, Mukherjee A, et al. EphA2 mediates ligand-dependent inhibition and ligandindependent promotion of cell migration and invasion via a reciprocal regulatory loop with Akt. Cancer Cell. 2009; 16:9-20. [PubMed: 19573808]

90. Brantley-Sieders DM, Dunaway CM, Rao M, et al. Angiocrine factors modulate tumor proliferation and motility through EphA2 repression of Slit2 tumor suppressor function in endothelium. Cancer Res. 2011; 71:976-987. [PubMed: 21148069]

91. Dunaway CM, Hwang Y, Lindsley CW, et al. Cooperative signaling between Slit 2 and Ephrin-A1 regulates a balance between angiogenesis and angiostasis. Mol Cell Biol. 2011; 31:404-416. [PubMed: 21135133]

92. Macrae M, Neve RM, Rodriguez-Viciana P, et al. A conditional feedback loop regulates Ras activity through EphA2. Cancer Cell. 2005; 8:111-118. [PubMed: 16098464]

93. Brantley-Sieders DM, Caughron J, Hicks D, Pozzi A, Ruiz JC, Chen J. EphA2 receptor tyrosine kinase regulates endothelial cell migration and vascular assembly through phosphoinositide 3kinase-mediated Rac1 GTPase activation. J Cell Sci. 2004; 117:2037-2049. [PubMed: 15054110] 
94. Okazaki T, Ni A, Baluk P, et al. Capillary defects and exaggerated inflammatory response in the airways of EphA2-deficient mice. Am J Pathol. 2009; 174:2388-2399. [PubMed: 19443703]

95. Deroanne C, Vouret-Craviari V, Wang B, Pouyssegur J. EphrinA1 inactivates integrin-mediated vascular smooth muscle cell spreading via the Rac/PAK pathway. J Cell Sci. 2003; 116:13671376. [PubMed: 12615978]

96. Ogita H, Kunimoto S, Kamioka Y, Sawa H, Masuda M, Mochizuki N. EphA4-mediated Rho activation via Vsm-RhoGEF expressed specifically in vascular smooth muscle cells. Circ Res. 2003; 93:23-31. [PubMed: 12775584]

97. Leslie-Barbick JE, Shen C, Chen C, West JL. Micron-scale spatially patterned, covalently immobilized vascular endothelial growth factor on hydrogels accelerates endothelial tubulogenesis and increases cellular angiogenic responses. Tissue Eng Part A. 2011; 17:221-229. [PubMed: 20712418]

98. Shaut CA, Saneyoshi C, Morgan EA, Knosp WM, Sexton DR, Stadler HS. HOXA13 directly regulates EphA6 and EphA7 expression in the genital tubercle vascular endothelia. Dev Dyn. 2007; 236:951-960. [PubMed: 17304517]

99. Yang P, Yuan W, He J, et al. Overexpression of EphA2, MMP-9, and MVD-CD34 in hepatocellular carcinoma: implications for tumor progression and prognosis. Hepatol Res. 2009; 39:1169-1177. [PubMed: 19788698]

100. Dobaczewski M, Gonzalez-Quesada C, Frangogiannis NG. The extracellular matrix as a modulator of the inflammatory and reparative response following myocardial infarction. J Mol Cell Cardiol. 2010; 48:504-511. [PubMed: 19631653]

101. Cleutjens JP, Creemers EE. Integration of concepts: cardiac extracellular matrix remodeling after myocardial infarction. J Card Fail. 2002; 8:S344-S348. [PubMed: 12555143]

102. Levick SP, Melendez GC, Plante E, McLarty JL, Brower GL, Janicki JS. Cardiac mast cells: the centrepiece in adverse myocardial remodelling. Cardiovasc Res. 2011; 89:12-19. [PubMed: 20736239]

103. Brower GL, Chancey AL, Thanigaraj S, Matsubara BB, Janicki JS. Cause and effect relationship between myocardial mast cell number and matrix metalloproteinase activity. Am J Physiol Heart Circ Physiol. 2002; 283:H518-H525. [PubMed: 12124196]

104. de Almeida A, Mustin D, Forman MF, Brower GL, Janicki JS, Carver W. Effects of mast cells on the behavior of isolated heart fibroblasts: modulation of collagen remodeling and gene expression. J Cell Physiol. 2002; 191:51-59. [PubMed: 11920681]

105. Arslan F, Smeets MB, Riem Vis PW, et al. Lack of fibronectin-EDA promotes survival and prevents adverse remodeling and heart function deterioration after myocardial infarction. Circ Res. 2011; 108:582-592. [PubMed: 21350212]

106. Andrassy M, Volz HC, Igwe JC, et al. High-mobility group box-1 in ischemia-reperfusion injury of the heart. Circulation. 2008; 117:3216-3226. [PubMed: 18574060]

107. Oozawa S, Mori S, Kanke T, et al. Effects of HMGB1 on ischemia-reperfusion injury in the rat heart. Circ J. 2008; 72:1178-1184. [PubMed: 18577832]

108. Lu Q, Rounds S. Focal adhesion kinase and endothelial cell apoptosis. Microvasc Res. 2012; 83:56-63. [PubMed: 21624380]

109. Miao H, Burnett E, Kinch M, Simon E, Wang B. Activation of EphA2 kinase suppresses integrin function and causes focal-adhesion-kinase dephosphorylation. Nat Cell Biol. 2000; 2:62-69. [PubMed: 10655584]

110. Marber MS, Rose B, Wang Y. The p38 mitogen-activated protein kinase pathway-a potential target for intervention in infarction, hypertrophy, and heart failure. J Mol Cell Cardiol. 2011; 51:485-490. [PubMed: 21062627]

111. Carter N, Nakamoto T, Hirai H, Hunter T. EphrinA1-induced cytoskeletal reorganization requires FAK and p130(cas). Nat Cell Biol. 2002; 4:565-573. [PubMed: 12134157]

112. Hakim ZS, DiMichele LA, Rojas M, Meredith D, Mack CP, Taylor JM. FAK regulates cardiomyocyte survival following ischemia/reperfusion. J Mol Cell Cardiol. 2009; 46:241-248. [PubMed: 19028502]

113. Greenberg RS, Bernstein AM, Benezra M, Gelman IH, Taliana L, Masur SK. FAK-dependent regulation of myofibroblast differentiation. FASEB J. 2006; 20:1006-1008. [PubMed: 16585062] 
114. Mansson-Broberg A, Siddiqui AJ, Genander M, et al. Modulation of ephrinB2 leads to increased angiogenesis in ischemic myocardium and endothelial cell proliferation. Biochem Biophys Res Commun. 2008; 373:355-359. [PubMed: 18571496]

115. Virag JA, Lust RM. Coronary artery ligation and intramyocardial injection in a murine model of infarction. J Vis Exp. 2011; 52:2581. [PubMed: 21673649]

116. Frieden LA, Townsend TA, Vaught DB, et al. Regulation of heart valve morphogenesis by Eph receptor ligand, ephrin-A1. Dev Dyn. 2010; 239:3226-3234. [PubMed: 20960543]

117. Genet G, Guilbeau-Frugier C, Honton B, et al. Ephrin-B1 Is a novel specific component of the lateral membrane of the cardiomyocyte and is essential for the stability of cardiac tissue architecture cohesion. Circ Res. 2012; 110:688-700. [PubMed: 22302788] 


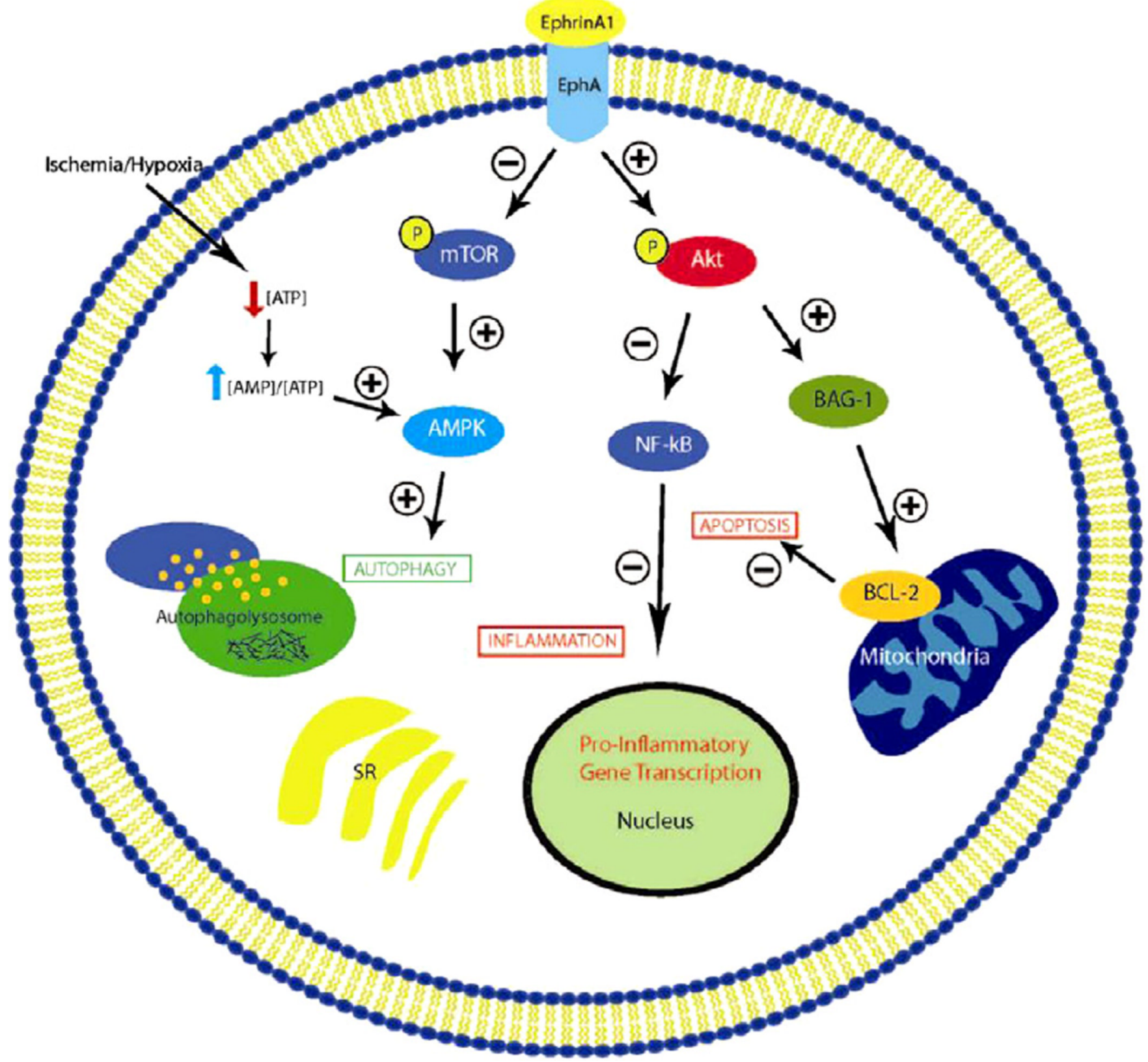

Figure 1.

Potential/hypothetical pathways modified by EphrinA1-EphA signaling. EphrinA1 potentially mediates cardioprotection during myocardial infarction by increasing phosphorylated-Akt to decrease apoptosis through upregulating bcl-2 and decreases the inflammatory response through the downregulation of NF- $\kappa$ B. The possible promotion of autophagy is mediated through the downregulation of mTOR and subsequent increase in AMPK. 
Table 1

Ephrin-Eph signaling in myocardium.

\begin{tabular}{llll}
\hline Study & Ephrin-Eph signaling & Model & Results \\
\hline Mansson-Broberg et al. [114] & EphB4, EphrinB2 & Nonreperfused coronary ligation & EphrinB2 role in angiogenesis \\
Dries et al. [27] & EphA Family, EphrinA1 & Nonreperfused coronary ligation & EphrinA1 role in myocardial protection \\
Goichberg et al. [28] & EphrinA1 & Human cardiac stem cells & EphrinA1 role in myocardial protection \\
Genet et al. [117] & EphrinB1 & Isolated CM studies & EphrinB1 role in CM structure stability \\
\hline
\end{tabular}

